(JPP) Jurnal Kesehatan Poltekkes Palembang

Vol. 14, No. 1, Juni 2019, eISSN 2654-3427

\title{
PEMBERIAN JUS KURLAPA DALAM MENINGKATKAN KADAR HEMOGLOBIN PADA REMAJA PUTRI YANG ANEMIA DI MA AL-MU'AAWANAHOGAN ILIR
}

\section{THE EFFECT OF KURLAPA JUICE TO IMPROVING HEMOGLOBIN LEVEL IN ANEMIA TEENAGER AT MA AL MU'AAWANAH OGAN ILIR}

\author{
Kurniati Ilahi, ${ }^{1}$ Susyani, ${ }^{1}$ Terati ${ }^{1}$ \\ ${ }^{1}$ Jurusan Gizi, Politeknik Kementrian Kesehatan Palembang, Sumatera Selatan, Indonesia \\ (email penulis korespodensi) : suzie.ani78@gmail.com
}

Info Artikel: Diterima: 20 April 2019

Revisi: 24 Mei 2019

Diterima: 31 Mei 2019

\begin{abstract}
ABSTRAK
Latar belakang: Anemia merupakan kekurangan sel darah merah (eritrosit), umumnya sebagai akibat dari kekurangan zat besi dari konsumsi makanan atau kehilangan darah yang berlebihan. Defisiensi lainnya yang juga dapat menyebabkan anemia, termasuk defisiensi vitamin B12 atau asam folat (anemia megaloblastik), vitamin $\mathrm{E}$ atau perdarahan/ hemorangi (anemia hemolitik). Kurma mengandung zat besi dan vitamin $\mathrm{C}$ yang tinggi dan dapat digunakan untuk pengobatan anemia. Vitamin C berperan dalam meningkatkan penyerapan zat besi. Selain kurma, air kelapa muda (Cocos Nucifera $L$ ) juga mengandung zat gizi yang dapat membantu pembentukan darah yaitu asam folat sebagai bahan pokok pembentuk inti sel hemoglobin. Tujuan penelitian ini untuk mengetahui pengaruh pemberian jus Kurlapa yang berbahan dasar dari kurma dan air kelapa muda dalam meningkatkan hemoglobin penderita anemia pada remaja putri.

Metode: Desain penelitian ini adalah quasi eksperimen dengan rancangan penelitian pre-test and post-test without control group. Penelitian ini dilakukan pada bulan Januari-April 2019.

Hasil penelitian diketahui rata-rata peningkatkan hemoglobin adalah $0,8600 \mathrm{~g} / \mathrm{dl}$. Hasil uji statistik (uji t-dependen) didapatkan nilai $p$ value $=0.000(p<0,05)$.

Kesimpulan: Jus Kurlapa berpengaruh dalam meningkatkan hemoglobin penderita anemia pada remaja putri di MA AL-Mu'aawanah Ogan Ilir.
\end{abstract}

Kata Kunci: Anemia, Hemoglobin, Jus Kurlapa.

\section{ABSTRACT}

Background: Anemia is a deficiency of red blood cells (erythrocytes), generally as a result of iron deficiency from food consumption or excessive blood loss. Other deficiencies that can also cause anemia, including vitamin B12 or folic acid deficiency (megaloblastic anemia), vitamin E or bleeding / hemorangi (hemolytic anemia). Dates contain hight iron and vitamin $C$ can be used for the treatment of anemia. Vitamin C plays a role in increasing iron absorption. In addition to dates, young coconut water (Cocos Nucifera L) also contains nutrients that can help the formation of blood, namely folic acid as the main ingredient for forming the hemoglobin cell nucleus. The objective study was known the effect of Kurlapa juice based on dates and young coconut water to increase hemoglobin in anemia patients in young women. The design of this research was quasi-experimental with pre-test and posttest without control group.

Methods: This research was conducted in January-April 2019. Based on the result of the study, the average increase in hemoglobin is $0.8600 \mathrm{~g} / \mathrm{dl}$. The results of the statistical test (t-dependent test) obtained $p$ value $=0.000(p<0.05)$.

Conclusion: Kurlapa juice has the influence to increase the hemoglobin of anemia patients in young women at MA AL-Mu'aawanah Ogan Ilir.

Keywords: Anemia, Hemoglobin, Kurlapa Juice 


\section{PENDAHULUAN}

Anemia merupakan kekurangan sel darah merah (eritrosit), umumnya sebagai akibat dari kekurangan zat besi dari konsumsi makanan atau kehilangan darah yang berlebihan. Defisiensi lainnya juga dapat menyebabkan anemia, termasuk defisiensi vitamin B12 atau asam folat (anemia megaloblastik), vitamin $\mathrm{E}$ atau perdarahan/ hemorangi (anemia hemolitik). Pengukuran yang sering dilakukan adalah dengan mengukur kadar hemoglobin dalam darah. Batas anemia berbeda menurut umur dengan keadaan fisiologis. Disebut anemia pada anak balita jika kadar hemoglobin (hb) kurang dari $11 \mathrm{gram} / \mathrm{dL}$, anak usia sekolah kurang dari 12 gram/dL, laki-laki dewasa kurang dari 13 gram/dL, ibu hamil kurang dari 11 gram/ dL, ibu menyusui (lebih dari 3 bulan) kurang dari 12 gram/ dL. ${ }^{1}$

Menurut Riset Kesehatan Dasar (Riskesdas) yang dilakukan pada tahun 2013 didapatkan bahwa prevalensi anemia defisiensi zat besi pada remaja menurut jenis kelamin, yaitu: pada anak perempuan sekitar $22,7 \%$ dan pada anak laki-laki $12,4 \%$ sedangkan menurut

\section{BAHAN DAN METODE}

Penelitian ini merupakan penelitian Quasi Eksperiment dengan rancangan pretest and postest without control group.

Subjek penelitian ini adalah Remaja putri yang mengalami anemia di MA ALMu'aawanah Ogan Ilir. Penelitian dilakukan pada bulan Januari-April 2019. Kriteria inklusi penelitian ini (1) Remaja putri kelas X dan XI di MA Al-Mu'aawanah, (2) Berusia 15-18 tahun (3) Bersedia menjadi responden, (4) Memiliki $\mathrm{Hb}<12$ gr/dl,(5) Sampel tidak sedang sakit, (6) Bersedia mengikuti kegiatan sampai selesai

Penentuan responden ditentukan menggunakan simple random sampling. Jumlah

\section{HASIL}

Distribusi Kejadian Anemia dan Asupan gizi responden terdiri dari energi, protein, Asam Folat, Zat besi, Vitamin $\mathrm{C}$ di MA AL- tempat tinggal, yaitu: desa $18,5 \%$ dan perkotaan $17,3 \%{ }^{2}$

Salah satu cara penanggulangan anemia dengan mengubah pola konsumsinya menjadi lebih baik, salah satunya yaitu dengan membuka pikiran bahwa khasiat buah-buahan sangatlah membantu, salah satunya yaitu buah kurma dan air kelapa muda. Kurma mengandung zat besi. Kandungan zat besi yang tinggi dapat digunakan untuk pengobatan anemia. Adanya zat besi dalam kurma nantinya diserap oleh usus dan dibawa oleh darah untuk hemopoiesis (proses pembentukan darah).air kelapa muda (Cocos Nucifera L) juga mengandung beberapa kandungan bahan yang dapat membantu pembentukan darah yaitu asam folat sebagai bahan pokok pembentuk inti sel darah merah. ${ }^{3}$ Tujuan penelitian ini untuk mengetahui pengaruh pemberian jus Kurlapa yang berbahan dasar dari kurma dan air kelapa muda dalam meningkatkan hemoglobin penderita anemia pada remaja putri.

responden yaitu 25 orang dan diberi perlakuan dengan konsumsi jus kurlapa yang terbuat dari buah kurma 150 gram dan air kelapa muda $250 \mathrm{ml}$. Jus kurlapa sebanyak $300 \mathrm{ml}$ dikonsumsi dengan frekuensi satu kali sehari selama 7 hari.

Hemoglobin responden diukur menggunakan alat digital Hemoglobinmeter sebelum dilakukan intervensi kemudian diukur kembali setelah diberikan intervensi selama 7 hari. Karakteristik responden dan asupan responden dianalisis menggunakan analisis deskriptif sedangkan perbedaan Hemoglobin sebelum dan sesudah intervensi kedua kelompok diuji dengan paired sample t-test..

Mu'aawanah disajikan pada Tabel 1 dan Tabel 2 dibawah ini: 
Tabel 1. Kejadian Anemia di MA AL-Mu'aawanah

\begin{tabular}{lcc}
\hline Karakteristik Responden & n & $\begin{array}{c}\text { Persentase } \\
(\%)\end{array}$ \\
\hline $\begin{array}{l}\text { Kejadian Anemia } \\
\text { 1. Anemia }\end{array}$ & 54 & 50,5 \\
2. Tidak Anemia & 53 & 49,5 \\
\hline Umur & & \\
1. 15 tahun & 7 & 28 \\
2. 16 tahun & 12 & 48 \\
3. 17 tahun & 6 & 24 \\
\hline
\end{tabular}

Tabel 2. Asupan Gizi Responden

\begin{tabular}{lcc}
\hline Asupan Gizi & n & $\begin{array}{c}\text { Persentase } \\
(\boldsymbol{\%})\end{array}$ \\
\hline Energi & 24 & 96 \\
1. Baik & 1 & 4 \\
2. Kurang & & \\
Protein & 22 & 88 \\
1. Baik & 3 & 12 \\
2. Kurang & & \\
Asam Folat & 7 & 28 \\
1. Baik & 18 & 72 \\
2. Kurang & & \\
Fe & 11 & 44 \\
1. Baik & 14 & 56 \\
2. Kurang & & \\
Vit C & 178 & 68 \\
1. Baik & & 32 \\
2. Kurang & & \\
\hline
\end{tabular}

Berdasarkan Tabel 1 diatas diketahui bahwa responden yang mengalami anemia sebanyak $50,5 \%$, sebagian besar responden berusia 16 tahun yaitu sebanyak 48,0\%. Dari Tabel 2 diatas diketahui bahwa setelah dilakukan intervensi, sebagian besar responden memiliki asupan energi dalam kategori baik sebesar 96,0\% . asupan protein dalam kategori kurang yaitu sebesar $12,0 \%$ asupan asam folat dalam kategori kurang yaitu sebesar $72,0 \%$, asupan zat besi dalam kategori kurang yaitu sebesar 56,0\% , asupan vitamin $\mathrm{c}$ dalam kategori kurang yaitu sebesar 32,\%. Perbedaan Rata-rata Hemoglobin Awal dan Akhir dijelaskan pada Tabel 3 dibawah ini:

Tabel 3. Perbedaan Rata-rata Hemoglobin Awal dan Akhir

\begin{tabular}{ccccc}
\hline $\begin{array}{c}\text { Jenis } \\
\text { Pemeriksaan }\end{array}$ & $\begin{array}{c}\text { Mean awal } \pm \\
\text { SD }\end{array}$ & Mean akhir \pm SD & Nilai p & t \\
\hline Hemoglobin & $11,116 \pm$ & & & \\
& 0.5520 & 0,5387 & 0,0005 & $-16,866$ \\
& & & & \\
\hline
\end{tabular}


Dari Tabel di atas menunjukan bahwa ratarata $\mathrm{Hb}$ sebelum diberi jus kulapa yaitu $11,116 \mathrm{~g} / \mathrm{dl}$. rata-rata $\mathrm{Hb}$ setelah diberi jus kulapa yaitu $11,976 \mathrm{~g} / \mathrm{dl}$. Peningkatan rata-rata kadar hemoglobin remaja putri setelah pemberian jus

\section{PEMBAHASAN}

Sebagian besar responden berusia 16 tahun yaitu sebanyak 12 orang $(48,0 \%)$. Penderita anemia paling banyak berada di kisaran uisa 15-16 tahun. Hal ini dikarenakan pada usia tersebut remaja mengalami menstruasi setiap bulannya yang akan berpengaruh kehilangan zat besi pada saat menstruasi, sedangkan remaja pada usia ini tidak memperhatikan asupan zat gizi yang dikonsumsikan untuk mengembalikan zat besi yang hilang karena menstruasi. ${ }^{4}$ Hasil dari tabel 2 diatas dapat diketahui bahwa responden memiliki asupan energi dalam kategori baik sebesar 96,0\%.

Berdasarkan hasil wawancara, responden mengkonsumsi nasi sebagai bahan makanan pokok dalam porsi yang cukup. Responden juga sering mengkonsumsi mie instan, makanan jajanan seperti cilok, pempek, sosis dan bakso. Dalam penelitian ini diketahui Asupan protein dalam kategori kurang baik sebesar 12,0\% dan dalam kategori baik sebesar $88,0 \%$. Berdasarkan hasil wawancara, responden hanya mengkonsumsi salah satu jenis protein seperti protein nabati saja atau protein hewani saja. Protein yang sering dikonsumsi berasal dari hewani seperti telur dan ayam namun tidak dalam jumlah yang mencukupi kebutuhan responden. Sedangakan jenis protein nabati yang sering dikonsumsi yaitu tempe.

Hal tersebut juga sejalan dengan penelitian yang dilakukan pada siswa SMAN 3 Ponorogo, yang menyimpulakn bahwa terdapat hubungan yang bermakna antara tingkat konsumsi protein dengan kadar haemoglobin dengan $(\mathrm{p}=0,000){ }^{6}$ Pada asupan zat besi, dari hasil penelitian diketahui bahwa sebagian besar asupan zat besi responden dalam kategori kurang baik sebesar 56,0\%. Berdasarkan hasil wawancara, responden jarang mengkonsumsi bahan makanan yang mengandung zat besi heme seperti daging, hati dan ikan. Sebagian besar responden mengkonsumsi besi non heme seperti bayam, tempe dan tahu, padahal penyerapan besi non heme lebih rendah dibandingkan besi heme. ${ }^{8}$

Asupan vitamin $\mathrm{C}$ responden dalam kategori kurang baik sebesar $32,0 \%$ dan dalam kategori baik sebesar $68,0 \%$. Berdasarkan hasil kurlapa yaitu $0,8600 \mathrm{~g} / \mathrm{dl}$. Berdasarkan uji statistik (uji t-dependen) didapatkan nilai $p$ value $=0,0005(p<0,05)$.

wawancara, sebagian besar responden sudah cukup mengkonsumsi bahan makanan yang mengandung vitamin $\mathrm{C}$ dari buah dan sayur. Sebagian besar responden mengkonsumsi makanan sumber vitamin $C$ seperti pada berbagai sayuran hijau, kubis, labu kuning, jeruk dan pepaya sehingga asupan vitamin $\mathrm{C}$ responden dalam kategori baik.

Penelitian yang dilakukan di SMA N 1 Panarukan yang menunjukkan adanya hubungan antara asupan Vitamin C dengan Kadar Hemoglobin. ${ }^{9}$ Absorbsi besi dalam bentuk non hem meningkat empat kali lipat bila ada vitamin C. Vitamin $\mathrm{C}$ berperan dalam memindahkan besi dari transferin di dalam plasma ke ferritin. ${ }^{10}$ Penelitian terdahulu juga terbukti bahwa kurma yang mengandung vitamnin $\mathrm{C}$ yang tinggi dapat meningkatkan kadar haemoglobin remaja putri. ${ }^{11}$ Pembentukan hemoglobin memerlukan beberapa zat gizi yang berperan dalam pembentukan sel darah merah, yang paling penting adalah zat besi, asam folat dan membutuhkan vitamin $\mathrm{C}$ untuk membantu penyerapan dalam zat besi dalam tubuh. Tanpa zat gizi tersebut, pembentukan sel darah merah tidak akan mencukupi. Selnya bisa memiliki kelainan bentuk dan tidak mampu mengangkut oksigen sebagaimana mestinya. ${ }^{12}$

Zat besi di dalam kurma dibutuhkan untuk produksi sel darah merah, besi diserap ke dalam darah untuk disalurkan ke sumsum tulang dan akan digunakan untuk membentuk hemoglobin bagi sel darah merah baru. ${ }^{13}$ Selain zat besi, kurma juga mengandung vitamin $\mathrm{C}$ yang memegang peran penting dalam proses penyerapan zat besi. Hal ini dikarenakan vitamin $\mathrm{C}$ berfungsi sebagai pereduksi ion feri menjadi ion fero yang merupakan suatu bentuk zat besi yang mudah diserap. Vitamin $\mathrm{C}$ dapat mencegah anemia dengan cara meningkatkan penyerapan besi dari usus atau dengan membantu mobilisasi besi dan disimpan tubuh. ${ }^{15}$ 
Air kelapa muda juga mengandung beberapa kandungan gizi yang membantu proses hematopoiesis. Air kelapa muda mengandung Asam folat yang diperlukan dalam

\section{KESIMPULAN DAN SARAN}

Pemberian Jus Kurlapa sebanyak 300 $\mathrm{ml}$ selama 7 hari berturut-turut menunjukkan ada pengaruh terhadap peningkatan Hemoglobin remaja putri yang mengalami anemia di MA AL-Mu'aawanah Ogan Ilir. Jus Kurlapa ini dapat menjadi salah satu

\section{UCAPAN TERIMA KASIH}

Penulis mengucapkan terima kasih kepada pihak-pihak yang telah membantu dalam

\section{DAFTAR PUSTAKA}

1. Sandjaja. 2009. Kamus Gizi. Jakarta. PT Kompas Medika Nusantara

2. Kemenkes RI. 2013. Riset Kesehatan Dasar; RISKESDAS. Jakarta: Balitbang Kemenkes RI

3. Yong, J W H. 2009. The Chemical and Biological Properties of Coconut (Cocos nucofera L.) Water. Molecules, 14.

4. Briawan, D, 2008, Penanggulangan anemia pada remaja, diakses 21 Maret 2009, http://widyakarya kusuma pangan dan gizi.com.

5. Rafirana. 2017. Hubungan antara pengetahuan tentang anemia, tingkat konsumsi protein, zat besi, dan vitamin $\mathrm{c}$ dengan kadar hemoglobin pada siswa sekolah menengah atas di SMAN 3 ponorogo. Universitas Muhammadiyah Surakarta.

6. Arifin U S., Nelly M., Julia R. 2013. Hubungan Asupan Zat Gizi Dengan Kejadian Anemia Pada Anak Sekolah Dasar Di Kabupaten Bolaang Mongondow Utara.

7. Chuluq Ar, A. Chusnul,dkk. 2012. Hubungan Intake Zat Besi (Fe), Inhibitor, dan Enhancer Dengan Kadar Hemoglobin berbagai jenis reaksi biokimia. Asam folat diperlukan untuk pembentukan sel darah merah dan pendewasaannya dalam sumsum tulang.

pertimbangan untuk mencegah dan mengatasi anemia terutama pada remaja putri.

Perlu dilakukan penelitian lanjutan yang mempertimbangkan asupan zat gizi responden agar hasil penelitian dapat menggambarkan tentang tingkat konsumsi zat gizi dan hubungan dengan kejadian anemia gizi.

pelaksanaan penelitian dan penulisan karya ilmiah ini.

Remaja Putri (Studi Kasus Di SMAN 1 Panarukan Kecamatan Panarukan, Kabupaten Situbondo). Fakultas Kedokteran Universitas Brawijaya

8. Almatsier, S. 2001. prinsip Dasar Ilmu Gizi. Jakarta : Gramedia Pustaka Utama.

9. Cholifah N. 2017. Aplikasi pemberian kurma sebagai upaya peningkatan kadar hemoglobin pada remaja putri yang mengalami anemia. Yogyakarta.

10. Wirakusumah, 1999. Perencanaan Menu Anemia Gizi Besi. PT Pustaka Pembangunan Swadaya Nusantara. Jakarta.

11. Anita. 2013. Hubungan antara Asupan Zat Besi, Protein, dan Vitamin $\mathrm{C}$ dengan Kejadian Anemia pada Anak Sekolah Dasar di Kelurahan Bunaken Kecamatan Bunaken Kepulauan Kota Manado. Indonesian Journal of Public Health. 3 (1).

12. Rahana D D.,Panunggal B.,Pramono A., Yudi D. 2018. Hubungan asupan protein dan kebiasaan makan pagi terhadap kadar hemoglobin pada anak usia 9-12 tahun di tambaklorok semarang utara. Departemen Ilmu Gizi, Fakultas Kedokteran, Universitas 